\title{
Comparative Effects of Photodynamic Therapy mediated by Curcumin on Standard and Clinical Isolate of Streptococcus mutans
}

\author{
${ }^{1}$ Caroline C Tonon, ${ }^{2}$ Marco Aurélio Paschoal, ${ }^{3}$ Marilia Correia, ${ }^{4}$ Denise MP Spolidório, ${ }^{5}$ Vanderlei S Bagnato \\ ${ }^{6}$ Juçaíra SM Giusti, ${ }^{7}$ Lourdes Santos-Pinto
}

\begin{abstract}
Aim: The aim of this study was investigate the effect of photodynamic therapy (PDT) using curcumin (C) as a photosensitizing agent irradiated with an LED (L) in the blue wavelength as a light source on a standard and clinical isolate of Streptococcus mutans (S. mutans) in a planktonic suspension model.
\end{abstract}

Materials and methods: Suspensions of both strains were divided into 4 groups as follows: absence of $C$ and $L$ (control group: $C-L-)$, with $C$ and without $L$ ( $C$ group: $C+L-)$, absence of $C$ with $L$ ( $L$ group: $C-L+$ ) and presence of $C$ and $L$ (PDT group: $\mathrm{C}+\mathrm{L}+)$. Three different concentrations of curcumin $(0.75 \mathrm{mg} / \mathrm{ml}$, $1.5 \mathrm{mg} / \mathrm{ml}$ and $3 \mathrm{mg} / \mathrm{ml}$ ) and three light fluences of studied light source $\left(24,48\right.$ and $\left.72 \mathrm{~J} \mathrm{~cm}^{-2}\right)$ were tested. Aliquots of each studied group was plated in $\mathrm{BHI}$ agar and submitted to colony forming units counting $(\mathrm{CFU} / \mathrm{ml})$ and the data transformed into logarithmical scale.

Results: A high photoinactivation rate of more than $70 \%$ was verified to standard $S$. mutans strain submitted to PDT whereas the clinical isolate showed a lower sensitivity to all the associations of curcumin and LED. A slight bacterial reduction was verified to $C+L-$ and $C-L+$, demonstrating no toxic effects to the isolated application of light and photosensitizer to both S. mutans strains tested.

Conclusion: Photodynamic therapy using a combination of curcumin and blue LED presented a substantial antimicrobial effect on $S$. mutans standard strain in a planktonic suspension model with a less pronounced effect on its clinical isolate counterparts due to resistance to this alternative approach.

\footnotetext{
${ }^{1}$ Araraquara Dental School, Universidade Estadual Paulista Araraquara, São Paulo, Brazil

${ }^{2}$ Master Program in Dentistry, CEUMA University, São Luís Maranhão, Brazil

${ }^{3,7}$ Department of Pediatric Dentistry, Araraquara Dental School Universidade Estadual Paulista, Araraquara, São Paulo, Brazil

${ }^{4}$ Department of Pathology and Physiology, Araraquara Dental School, Universidade Estadual Paulista, Araraquara, São Paulo, Brazil

${ }^{5,6}$ São Carlos Institute of Physics, University of São Paulo São Carlos, São Paulo, Brazil
}

Corresponding Author: Lourdes Santos-Pinto, PhD Araraquara Dental School, Universidade Estadual Paulista, Rua Humaitá, 1680 Araraquara, São Paulo 14801-903, Brazil Phone: 5516 33016330, Fax: 551633016328 , e-mail: Ispinto@ foar.unesp.br
Clinical significance: Alternative antimicrobial approaches, as photodynamic therapy, should be encouraged due to optimal results against cariogenic bacteria aiming to prevent or treat dental caries.

Keywords: Streptococcus mutans, Photochemotherapy, Curcumin.

How to cite this article: Tonon CC, Paschoal MA, Correia M, Spolidório DMP, Bagnato VS, Giusti JSM, Santos-Pinto L. Comparative Effects of Photodynamic Therapy mediated by Curcumin on Standard and Clinical Isolate of Streptococcus mutans. J Contemp Dent Pract 2015;16(1):1-6.

\section{Source of support: Nil}

Conflict of interest: None

\section{INTRODUCTION}

It is known that Streptococcus mutans (S. mutans) is a substantial part of the dental plaque microbiota and its importance in the dental caries etiology.

The mechanical removal of dental plaque is a fundamental aspect to decrease the levels of pathogenic microorganisms involved with the progression of this oral disease. ${ }^{2}$ However, bacterial reservoirs can remain on tooth surface, since the dental plaque debridement is dependent of dexterity and compliance of the individuals. ${ }^{3}$ Thus, adjunctive methods are encouraged to control bacterial proliferation in the mouth environment, such as antimicrobial chemical substances.

Chlorhexidine has a greater in vivo immediate antibacterial effect and a greater substantivity than other antiseptics used in the oral cavity. ${ }^{4}$ However, probably due to difficulties in obtaining a long and significant decrease in the $S$. mutans resident cells after chlorhexidine regimen, ${ }^{5}$ the indiscriminate use of this substance can generates some side effects as alteration in taste, teeth and restorations staining, burning sensation and bacterial resistance. $^{6}$

In the search for new strategies against microorganisms, photodynamic therapy (PDT) has been suggested as an alternative to chemical antimicrobial agents to avoid bacteria accumulation on dental substrata. ${ }^{7}$

Photodynamic therapy is a therapy modality that employs the com-bination of visible light, a drug (called 
photosensitizer - PS) and molecular oxygen present in the tissue. The used PS binds to the target cell and can be activated by light of a suitable wavelength. ${ }^{8}$ During this process, there is a production of free radicals and different reactive oxygen species (ROS), such as singlet oxygen that will lead a sequence of biological events resulting in microorganisms death. ${ }^{9}$ PDT represents an alternative antibacterial, ${ }^{10}$ antifungal, ${ }_{1}^{11}$ and antiviral treatment for drug-resistant organisms. ${ }^{12}$ It is not likely that bacteria would develop a resistance to the cytotoxic action of singlet oxygen or free radicals, due to different ROS action sites of damaged cells. ${ }^{9}$

Nowadays, there is a trend on the use of natural products in PDT field, since the PS used present high costs related to purification process (Photogem ${ }^{\circledR}$ and Photosan $\left.{ }^{\circledR}\right)^{13}$ and due to possibility of tooth staining (toluidine blue $\mathrm{O}$, methylene blue and malachite green). ${ }^{14}$

Curcumin, the major yellow pigment extracted from turmeric plant, is pointed out as a potent photoactivatable substance by recent investigations. ${ }^{15}$ This dye is commonly used as spice in traditional eastern cookery and exhibit a variety of pharmacological properties such as antitumor, anticancer, anti-inflammatory, antioxidants and antimicrobial activities, some of which could be enhanced by light application..$^{15}$ In addition, curcumin presents a broad absorption peak in the 300 to $500 \mathrm{~nm}$, which coincides with the blue light emission range. ${ }^{16}$

Several studies concerning PDT and curcumin present a high photoinactivation in cariogenic bacteria, ${ }^{15}$ candida species ${ }^{11}$ in planktonic suspension models ${ }^{15}$ and on its biofilms counterparts. ${ }^{17}$ Although the literature have demonstrated positive outcomes related to effectiveness of PDT on laboratory strains, investigations regarding clinical isolates are able to demonstrate, with more reliability, the behavior of antimicrobial approaches close to clinical conditions.

Therefore, the aim of this present investigation is compare the effectiveness of PDT mediated by different curcumin concentrations irradiated with a blue LED at different dosimetries on S. mutans standard and a clinical isolate in a planktonic suspension culture. The null hypothesis formulated was that there are no significant differences between the tested groups in comparison with control groups.

\section{MATERIALS AND METHODS}

\section{Light Source and Photosensitizer}

A blue light-emitting diode (Edixeon, Edison Opto Corporation, New Taipei City, Taiwan) with a power intensity of $240.1 \mathrm{mWcm}^{-2}$ was used. This light provided an absorption spectra with a central wavelength at $450 \mathrm{~nm}$ \pm 30 and the irradiances (energy fluency) tested were 24, 48 and $72 \mathrm{~J} \mathrm{~cm}^{-2}$ following a formula used by a previous study. ${ }^{18}$ The work distance to achieve the desired power intensity was fixed at $5 \mathrm{~mm}$ (distance between the light source and bacterial samples).

A solution of curcumin was prepared by PDT Pharma (Cravinhos - SP, Brazil) and dissolved in sterile distilled water to obtain the tested stock solutions at $0.75 \mathrm{mg} /$ $\mathrm{ml}, 1.5 \mathrm{mg} / \mathrm{ml}$ and $3 \mathrm{mg} / \mathrm{ml}$. The ultraviolet spectra of curcumin presented a maximum absorption at $430 \mathrm{~nm}$, spectral region that absorbs efficiently the delivered light (Graph 1).

\section{Preparation of the Microorganisms}

A standard suspension of S. mutans (strain ATCC 25175) was inoculated in brain heart infusion broth (BHI, Becton, Dickinson Company, Sparks, MD USA) and incubated for 18 hours at $37^{\circ} \mathrm{C}$ under micro-aerophilic condition $(10 \%$ of $\mathrm{CO}_{2}$ ). This bacterial culture was then centrifuged at 3000 RPM for 5 min and the supernatant was discarded. Then, the cell pellet was re-suspended in $5 \mathrm{ml}$ of sterile solution of $0.9 \%$ sodium chloride $(\mathrm{NaCl})$.

The cell numbers were measured by means of a spectrophotometer (wavelength, at $600 \mathrm{~nm}$ using a $0.15-0.20$ optical density unit equals $\sim 10^{7}$ cells ml${ }^{-1}$ ) in $1 \mathrm{ml}$ cuvettes.

To clinical isolate sample, a patient presenting dental caries history attending at Pediatric Dentistry Clinic of Araraquara Dental School was elected. To participate in this present investigation both patient and respective guardians signed an informed consent (Proc. \#54/10). A pooled plaque sample was collected with a sterile wood stick, transferred to a tube containing $\mathrm{BHI}$ and incubated by the same above conditions. A diluted sample was plated in agar plate and colonies similar to morphological

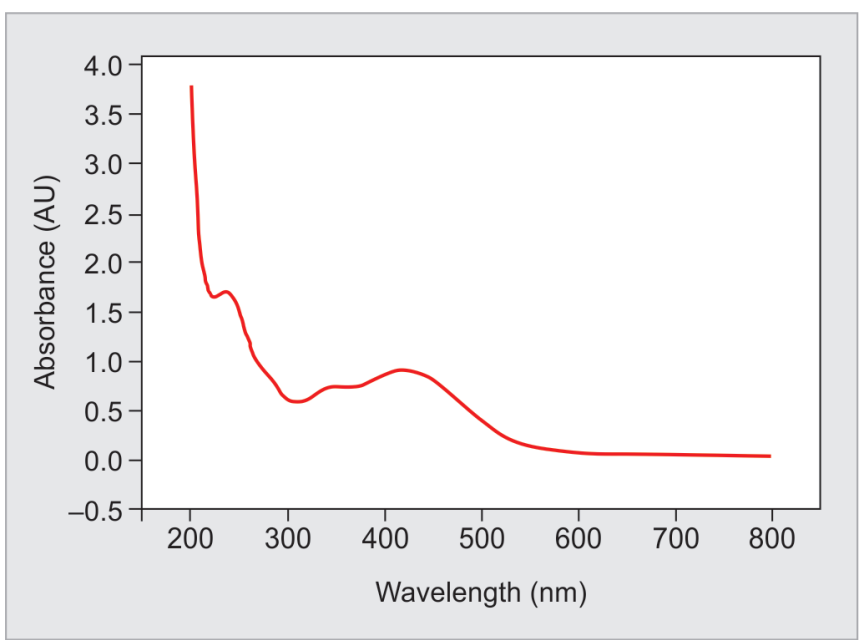

Graph 1: Absorption spectrum of curcumin dye 
aspects of $S$. mutans were isolated, reincubated and re-plated to verify the growth of this specific bacterium. To confirm this finding, the colonies were analyzed by microscopic technique and Gram test. After this, $S$. mutans clinical isolate was submitted to same procedures to standardize the number of viable cells.

\section{Photodynamic Therapy Application}

Aliquots of $500 \mu \mathrm{l}$ of both standard and clinical S. mutans suspensions were individually transferred to separate wells of a 24-well culture cell plate. On the day of the experiment, the curcumin solution was diluted in sterile saline concentrations and kept in the dark. An equal volume $(500 \mu \mathrm{l})$ of each standardized micro-organisms were added to the wells to give final tested concentrations at $0.75 \mathrm{mg} / \mathrm{ml}, 1.5 \mathrm{mg} / \mathrm{ml}$ and $3 \mathrm{mg} / \mathrm{ml}$. After dark incubation for 60 seconds, pre-irradiation time, the wells were illuminated by a blue LED device for 100, 200 and 300 seconds (corresponding to 24, 48 and $72 \mathrm{~J} \mathrm{~cm}^{-2}$, respectively) (treated with curcumin and LED - PDT group: $\mathrm{C}+\mathrm{L}+$ ). To determine whether curcumin alone induced any toxic effects on bacterial viability, additional wells containing the bacteria suspension were exposed to curcumin under identical conditions to those described above, but not exposed to LED (treated only with curcumin: Group $\mathrm{C}+\mathrm{L}-$ ). Exposing cells to irradiation determined the isolated effect of LED with no previous exposure to curcumin (treated only with LED: Group C-L+). The control wells consisted of both $S$. mutans suspensions exposed to neither curcumin nor LED (no treatment: C-L-; control group). Tenfold serial dilutions of the contents from each well were obtained and aliquots were transferred in triplicate to Petri dishes containing $\mathrm{BHI}$ agar. After incubation $\left(37^{\circ} \mathrm{C}\right.$ for 48 hours), the total number of colony forming units (CFU) was determined by using a digital colony counter (CP 600 Plus, Phoenix Ind. Com. Equipamentos Cientificos Ltda, Araraquara, SP, Brazil). The number of CFUs per millimeter $(\mathrm{CFU} / \mathrm{ml})$ was obtained and transformed into logarithm $\left(\log _{10}\right)$.

\section{STATISTICAL ANALYSIS}

In order to verify the differences between groups to both tested $S$. mutans strains, the variable reduction in viable bacterial colony counts promoted by each group was analyzed by two-way ANOVA and Tukey's test. The statistical significance cutoff level was set as $p<0.05$. The BioEstat 5.0 software for Windows (Sociedade Civil Mamiraua, Manaus, AM, Brazil) was used for data analysis.

\section{RESULTS}

Graph 2 shows the CFU values for each studied group to standard $S$. mutans strain. The group irradiated by blue LED in the presence of curcumin (PDT group: $\mathrm{C}+\mathrm{L}+$ ) presented a significantly lower number of viable bacteria $(\mathrm{p}<0.05)$ compared to control group. Reductions of $60.66 \%$ and $71.07 \%$ were verified when curcumin used at $1.5 \mathrm{mg} / \mathrm{ml}$ was irradiated at dosimetries of 48 and $72 \mathrm{~J} \mathrm{~cm}^{-2}$, respectively. On the other hand, S. mutans clinical isolate demonstrated a lower sensibility to PDT application. Graph 3 shows that to all the associations of curcumin and LED achieved the same CFU bacterial reduction $(33.88 \%)(p<0.05)$. The other groups, to both studied strains, revealed a slight reduction of viable bacteria without clinical significance in comparison to control group ( $p>0.05)$. Thus, based on these findings, the null hypothesis was partially accepted.

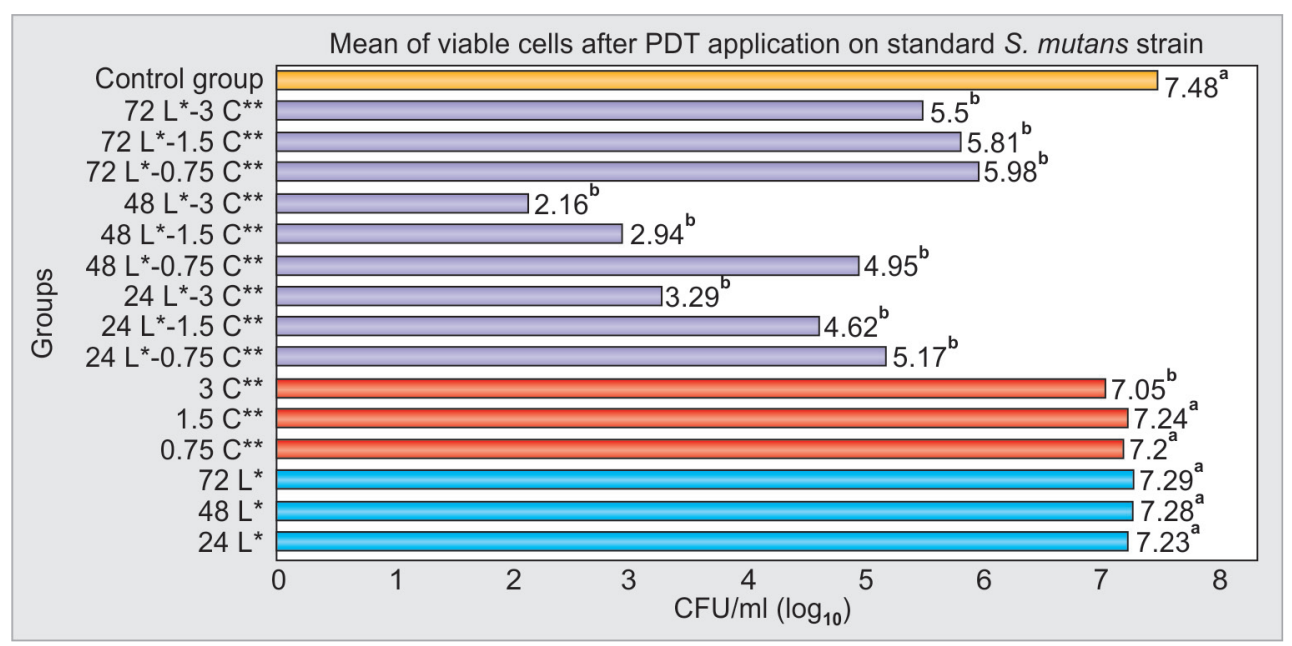

Graph 2: Mean of viable bacteria (colony forming units $/ \mathrm{ml}$ ) in $\log _{10}$ to all the experimental conditions to standard Streptococcus mutans (ATCC 25175). Data represent mean values $(n=6)$. Different lowercase letters represent difference statistically significant $(p<0.05)$ ( $\mathrm{C}^{*}$ : Curcumin at $\mathrm{mg} / \mathrm{ml}^{\circ} \mathrm{L}^{* *}$ : blue LED at $\mathrm{J} \mathrm{cm}^{-2}$ ) 


\section{DISCUSSION}

The outcomes of this present investigation demonstrated that the application of PDT mediated by curcumin activated with a blue LED was able to photoinactivate planktonic suspensions of $S$. mutans on both laboratorial standard and a clinical isolate strain. Although some studies have showed the success of this antimicrobial approach on cariogenic bacteria, none of these investigations has focused the behavior of PDT on clinical isolates of cariogenic bacteria. Recently, the success of curcumin-mediated PDT has been suggested by some authors. Araujo et $\mathrm{al}^{15}$ found a substantial bacterial reduction on planktonic suspensions of $S$. mutans and Lactobacillus acidophilus using $1.5 \mathrm{~g} / 1$ at $5.7 \mathrm{~J} \mathrm{~cm}^{-2}$ of a blue LED light source. In addition, Dovigo et al. ${ }^{11}$ photoinactivated species of Candida albicans with $5.28 \mathrm{~J} \mathrm{~cm}^{-2}$ in the presence of $20 \mu \mathrm{M}$ of curcumin. Still, an in vivo approach was able to decrease the levels of S. mutans present in saliva after a curcumin mouthrinse and subsequently exposure to a light at $450 \mathrm{~nm}$. Overall, due to simple manipulation, price and great effectiveness of curcumin associated with light source, PDT is a promising tool on dental practice. ${ }^{19}$

As a Gram-positive bacteria, S. mutans on both tested forms presented high sensitivity to PDT application. This behavior is explained by the structural differences of the outer bacterial cell wall between Gram-positive and Gramnegative bacteria, which decrease the efficacy of various photosensitizers. The 40 to $80 \mathrm{~nm}$ thick outer cell wall and up to 100 peptidoglycan layers of Gram-positive bacteria do not represent an effective permeability barrier. In contrast, the outer membrane of Gram-negative bacteria with a bilamellar membrane covering the only $3 \mathrm{~nm}$ thick peptidoglycan layer is able to prevent photosensitizer diffusion considerably, especially the negatively charged or neutral photosensitizers. Matiello et $\mathrm{al}^{20}$ verified a high resistance of Actinobacillus actinomycetemcomitans (A.a.) to photoinactivation in the presence of $0.01 \%$ of TBO irradiated with an AlGaInP diode laser light source in comparison to Streptococcus sanguinis, achieving a bacterial reduction of $61.53 \%$ and $84.32 \%$, respectively. Furthermore, due to the possibility of interchange among microorganisms in oral cavity, clinical strains are normally more resistant to antimicrobials chemotherapeutic agents than laboratory strains. In accordance of this statement, it was achieved a photokilling rate more than $70 \%$ on laboratorial standard strain whereas a rate of less than $40 \%$ was observed on its clinical sample counterpart. To corroborate with our findings, a photoinactivation of laboratorial strain of $C$. albicans was achieved with the association of $20 \mu \mathrm{M}$ of curcumin exposure to 5.28 $\mathrm{Jcm}^{-2}$ of a blue light source ${ }^{11}$ whereas clinical isolates of its counterparts, C. glabatra and C. tropicalis to achieve a significant antifungal effect was necessary a exposure of more than three times of irradiance $\left(18 \mathrm{~J} \mathrm{~cm}^{-2}\right)$ in the presence of $40 \mu \mathrm{M}$ of the same PS. ${ }^{21}$

In our study, neither curcumin nor light when used alone had a bactericidal effect. In fact, our results highlighted the need for dye-light conjugation to ensure the effectiveness of PDT. This outcome is in agreement with current photodynamic studies. ${ }^{11,15,20}$

The increase of curcumin concentration and light dosages did not demonstrated a bactericidal cumulative effect to both studied strains, indicating a nondose response to variable increments. To laboratorial S. mutans strain, the highest log bacterial reduction was achieved when exposure to $48 \mathrm{~J} \mathrm{~cm}^{-2}$ in the presence of $3 \mathrm{mg} /$ $\mathrm{ml}$ (difference of $5.32 \log _{10}$ in comparison with control group). However, at same curcumin concentration but with increased light fluency resulted in a difference of $1.98 \log _{10}$. Additionally, however the clinical isolate have

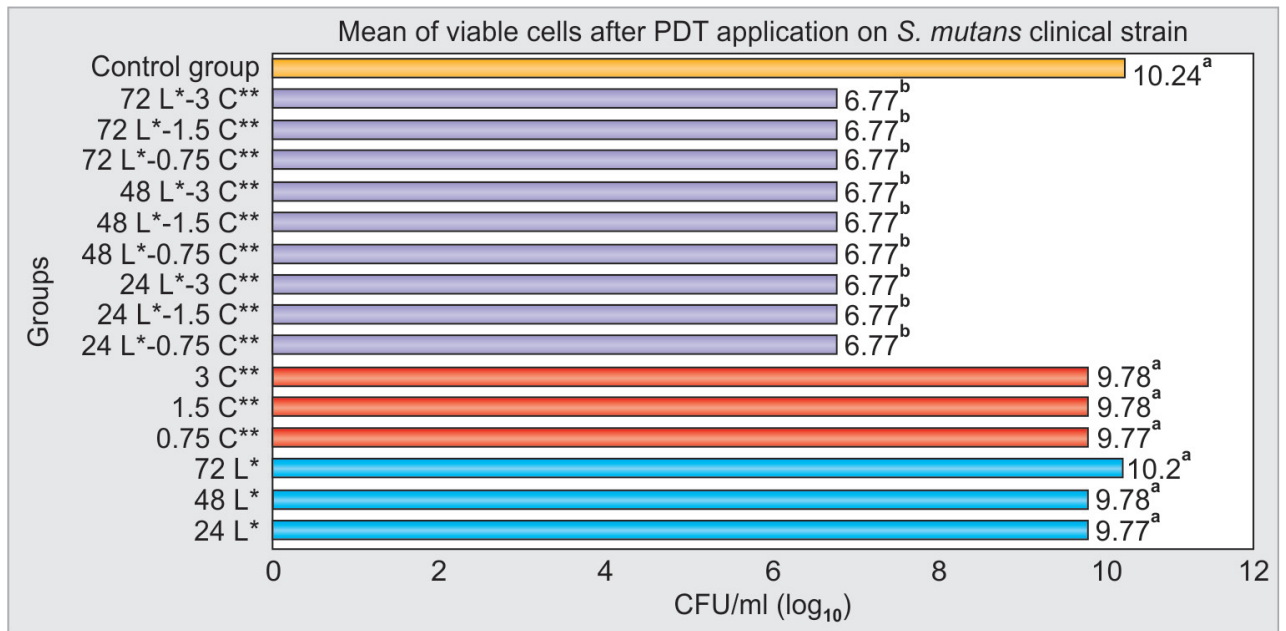

Graph 3: Mean of viable bacteria (Colony-forming unit/ml) in $\log _{10}$ to all the experimental conditions to Streptococcus mutans clinical isolate. Data represent mean values $(n=6)$. Different lowercase letters represent difference statistically significant $(p<0.05)\left(C^{*}\right.$ : Curcumin at $\mathrm{mg} / \mathrm{ml} ; \mathrm{L}^{* *}$ : blue LED at $\mathrm{J} \mathrm{cm}^{-2}$ ) 
showed more resistance to PDT application, a difference of $3.47 \log _{10}$ in comparison with control group at all studied PDT situations was verified. A similar nondose dependent pattern was obtained by some authors ${ }^{11,20,21}$ using this same PS and light source. On the contrary, study of Chan and $\mathrm{Lai}^{22}$ the exposure of periodontopathogenic bacteria to $665 \mathrm{~nm}$ diode laser with power output of $100 \mathrm{~mW}$ in the presence of $0.01 \%$ TBO resulted in a dose-dependent decrease of viable bacterial strains. Maintaining a constant power with an exposure time of $30 \mathrm{~s}$ and energy density of $10.6 \mathrm{~J} \mathrm{~cm}^{-2}$ resulted in a bacterial decrease between 71 and $88 \%$. Increasing the exposure to $60 \mathrm{~s}$ and energy density to $21.2 \mathrm{~J} \mathrm{~cm}^{-2}$, there was a 99 to $100 \%$ reduction of $P$. intermedia, $P$. gingivalis and S. sanguis, while A.a. and F. nucleatum numbers decrease by 95 and $96 \%$, respectively. On this same way, Paulino et $\mathrm{al}^{23}$ treated $S$. mutans with different concentrations of Rose Bengal (RB) (0-50 $\mu \mathrm{M})$ irradiated with a hand held photopolimerizer (400-500 nm) at different time periods showed that to concentrations from $0.1 \mu \mathrm{M}$ of $\mathrm{RB}$ and a time illumination of 30 seconds achieved a dose dependent pattern, achieving $100 \%$ of cell death at 0.5 $\mu \mathrm{M}$ of RB. This difference among the mentioned studies can be explained by the different ways of action of used photosensitizers. It has been proved that curcumin, when submitted to longer irradiation times, produced lower quantities of free radicals or singlet oxygen due to high photobleaching rate. ${ }^{11}$ There is a maximum of cell absorption related to PS or dyes utilized; an excess of dye in solution, corresponding to high concentrations, would blocks the light to reach bacteria, resulting in the optical quenching phenomenon. ${ }^{18}$

However, it is known that dental caries is resulted of biofilm accumulation on tooth surface ${ }^{24}$ the present investigation focused the PDT application on planktonic phase, which resulted in reduction of bacterial counts of both standard and clinical isolate of $S$. mutans reinforcing curcumin as a potent photosensitizer and establishing PDT as one of the strategies for caries treatment and prevention.

\section{CONCLUSION}

In accordance of our findings, the present study demonstrated that both tested $S$. mutans strains presented sensitivity to this antimicrobial tool mediated by curcumin and a LED in the blue wavelength, although more resistance was found to clinical isolate of $S$. mutans. More extensive investigations to elucidate the effectiveness of curcumin-mediated PDT should be encouraged on in situ studies and over biofilms structures aiming to define more accurate parameters to future PDT clinical applications.

\section{CLINICAL SIGNIFICANCE}

Alternative antimicrobial approach, as photodynamic therapy, is demonstrating good results against cariogenic bacteria and could be used to decrease the number of microorganism in oral cavity aiming to prevent or treat dental caries.

\section{ACKNOWLEDGMENTS}

The authors would like to thanks the skilful assistance of Dr Marilia Ferreira Correia to assist with the experimental phase. Furthermore, the Institute of Physics of São Carlos and the Center of Study in Optics and Photonics (CePOF) for developing the LED prototype used in this study and PDT Pharma to provide us the photosensitizer used in this study. This research was supported by Fundação de Amparo à Pesquisa do Estado de São Paulo-FAPESP \#2010/15763-1 (scholarship to Caroline C Tonon).

\section{REFERENCES}

1. Marsh PD. Dental as plaque biofilm and a microbial community: implications for health and disease. BMC Oral Health 2006;6(suppl 1):S1-S14.

2. Bernimoulin JP. Recent concepts in plaque formation. J Clin Periodontol 2003;30:7-9.

3. Wilson TG Jr. Compliance. A review of the literature with possible applications to periodontics. J Periodontol 1987; 58(10):706-714.

4. Jekins S, Addy M, Wade W, Newcombe RG. The magnitude and duration of the effects of some mouthrinse products on salivary bacterial counts. J Clin Periodontol 1994;21(6):397-401.

5. Caufield PW, Dasanayake AP, Li Y. The antimicrobial approach to caries management. J Dent Educ 2001;65(10): 1091-1095.

6. Charles $\mathrm{CH}$, Mostler KM, Bartels LL, Mankodi SM. Comparative antiplaque and antigingivitis effectiveness of a chlorhexidine and an essential oil mouthrinse: 6-month clinical trial. J Clin Periodontol 2004;31(10):878-884.

7. Zanin IC, Lobo MM, Rodrigues LK, Pimenta LA, Hofling JF, Gonçalves RB. Photosensitization of in vitro biofilms by toluidine blue $\mathrm{O}$ combined with a light-emitting diode. Eur J Oral Sci 2006;114(1):64-69.

8. Paulino TP, Ribeiro KF, Thedei G Jr, Tedesco AC, Ciancaglini P. Use of hand held photopolymerizer to photoinactivate Streptococus mutans. Arch Oral Biol 2005;50(3):353-359.

9. Dougherty TJ, Gomer CJ, Henderson BW. Photodynamic therapy. J Nat Cancer Inst 1998;90(12):889-905.

10. Bevilacqua IM, Nicolau RA, Khouri S, Bruqnera A Jr, Teodoro GR, Zângaro RA, et al. The impact of photodynamic therapy on the viability of Streptococcus mutans in a planktonic culture. Photomed Laser Surg 2007;25(6):513-518.

11. Dovigo LN, Pavarina AC, Ribeiro AP, Brunetti IL, Costa CA, Jacomassi DP, et al. Investigation of the photodynamic effects of curcumin against Candida albicans. Photochem Photobiol 2011;87(4):895-903.

12. Smetana Z, Ben-Hur E, Mendelson E, Salsberg S, Wagner P, Malik Z. Herpes simplex virus proteins are damaged following photodynamic inactivation with phthalocyanines. J Photochem Photobiol B 1998;44(1):77-83. 
13. Giusti JS, Santos-Pinto L, Pizzolito AC, Helmerson K, Carvalho-Filho E, Kurachi C, et al. Antimicrobial photodynamic action on dentin using a light-emitting diode light source. Photomed Laser Surg 2008;26(4):281-287.

14. Rolim JPML, Melo MAS, Guedes SF, Albuquerque Filho FB, Souza JR, Nogueira NAP, et al. The antimicrobial activity of photodynamic therapy against Streptococcus mutans using different photosensitizers. J Photochem Photobiol B 2012; 106:40-46.

15. Araújo NC, Fontana CR, Bagnato VS, Gerbi ME. Photodynamic effects of curcumin against cariogenic pathogens. Photomed Laser Surg 2012;30(7):393-399.

16. Dujic J, Kippenberger S, Ramirez-Bosca A, Diaz-Alperi J, Bereiter-Hahn J, Kaufmann R, et al. Curcumin in combination with visible light inhibits tumor growth in a xenograft tumor model. Int J Cancer 2009;124(6):1422-1428.

17. Lee YH, Park HW, Lee JH, Seo HW, Lee SY. The photodynamictherapy on Streptococcus mutans biofilms using erythrosine and dental halogen curing unit. Int J Oral Sci 2012;4(4):196-201.

18. Paschoal MA, Tonon CC, Spolidório DMP, Bagnato VS, Giusti JSM, Santos-Pinto L. Photodynamic potential of curcumin and blue LED against Streptococcus mutans in a planktonic culture. Photodiagnosis Photodyn Ther 2013;10(3): 313-319.

19. Araújo NC, Fontana CR, Gerbi MEM, Bagnato VS. Overallmouth disinfection by photodynamic therapy using curcumin. Photomed Laser Surg 2012;30(2):96-101.

20. Mattiello FD, Coelho AA, Martins OP, Mattiello RD, FerrãoJúnior JP. In vitro effect of photodynamic therapy on Aggregatibacter actinomycetemcomitans and Streptococcus sanguinis. Braz Dent J 2011;22(5):398-403.

21. Dovigo LN, Pavarina AC, Carmello JC, Machado AL, Brunetti IL, Bagnato VS. Susceptibility of clinical isolates of Candida to photodynamic effects of curcumin. Lasers Surg Med 2011; 43(9):927-934.

22. Chan $\mathrm{Y}$, Lai CH. Bactericidal effects of different laser wavelengths on periodontopathic germs in photodynamic therapy. Lasers Med Sci 2003;18(1):51-55.

23. Paulino TP, Ribeiro KF, Thedei G Jr, Tedesco AC, Ciancaglini $P$. Use of hand held photopolymerizer to photoinactivate Streptococcus mutans. Arch Oral Biol 2005;50(3):353-359.

24. Fontana CR, Abernethy AD, Som S, Ruggiero K, Doucette $\mathrm{S}$, Marcantonio RC, et al. The antibacterial effect of photodynamic therapy in dental plaque-derived biofilms. J Periodontal Res 2009;44(6):751-759. 